\title{
Research on Innovative Path of United Front in Dealing with Political-business Relation
}

\author{
Ye Zhao \\ Teaching and Research Department of Economics \\ Liaoning Provincial Party School of CPC \\ Shenyang, China
}

\begin{abstract}
The united front, as a political union, can play an important role in building a new political-business relation through the action mechanism of organizational embeddedness and political absorption. Chinese united front needs to be further improved in terms of embedding effect, integrity of elite cooptation and public policy consultation mechanism, so the innovation path in these aspects, such as organization embedding, elite co-optation and consulting absorption, will play a more important role in dealing with the political-business relation.
\end{abstract} path

Keywords—political-business relation; united front; innovation

\section{INTRODUCTION}

In the context of our country, when it comes to the political-business relation between government and enterprise, we must consider how to deal with the relation between entrepreneurs and the party? The united front, as a political union, embodies the common interests of political forces in various societies. So it has the characteristics of wide connection and high tolerance of heterogeneity. Through the concept, resources, channels and functions, it can play a role in resolving conflicts and achieving great unity. And such characteristics make the united front play a unique role in promoting the healthy development of the political-business relation. Therefore, the establishment of a new politicalbusiness cannot be done without the role of the united front, and its role is both necessary and feasible.

\section{ACTION MECHANISM OF UNITED FRONT IN DEALING WITH POLITICAL-BUSINESS RELATION}

The ruling party's action mechanism of handling the political-business relation is mainly composed of two aspects: organization embedding and political absorption. The role of two action mechanisms is mainly relied on the organizational framework of united front, so as to play the role and function of the united front in controlling, serving and leading the economy and enterprises.

\section{A. The United Front's Action Mechanism I: Organization Embedding}

The earliest embedding was put forward by Polanyi (Great Transformation: Political and Economic Origin of Our Times, Trade and Market in Early Imperialism). Polanyi thought that trading behavior is usually embedded in a long-term relationship involving trust which often eliminates the contradiction of trading. Granovetter, the founder of new economic sociology, considered that all kinds of social factors, base on that, have an important impact on the economy even a decisive impact. And it further complements the concept. In Evans's analysis on the involvement and influence of newly industrialized countries on economic transition, the concept of embeddedness autonomy is used firstly. So far it has also triggered the thought of how the political party can play its role. That is, its activities should be broken out of its own organization scope.

\section{B. The United Front's Action Mechanism II: Political Absorption}

Jin Yaoji, a sociologist in Hongkong, initially put forward political absorption, and he thought in the process of political absorption the government absorbs the political power represented by the elite or elite group in the society so as to realize the integration of elites at a certain level and establish a relaxed but integrated political society. In this way, it can be seen that political absorption is a kind of rule and administration and has a technical strategy. Its main purpose is giving and consolidating the legitimacy of rule, and its main function is improving the effectiveness of rule. In China, the ruling party is the main body to absorb, and society is the object. The specific performance is that the ruling party carries out the large scale recruitment and absorption of all kinds of elite groups by three ways of organization absorption, system absorption and consciousness absorption, so as to improve the legitimacy and effectiveness of its ruling. Organization absorption is the way that the social elite has an organizational identity, of which the specific way is to recruit social elites to join the party or to encourage them to participate in social organizations established and managed by the government. The system absorption is a way of attracting social elite groups to NPC, CPPCC and government departments to make them have organizational identities. Ideological absorption is a way of adjusting ideological values and principles to coordinate the different values and principles between the people and the social strata and form a consistent belief with systematic consensus. The preferred range of political absorption in China is the united front, which can be achieved by united front organizations such as democratic parties, the Federation of Industry and Commerce, and the CPPCC. While political 
absorption also plays an important role in the construction of political-business relation. The specific performance is the following two aspects: first, through elite co-optation, the ruling party can obtain the political identification of economic elite which is a system guarantee for good interaction of political-business relation; second, the absorption of public policy consultation can enable the ruling party to make timely adjustments to public policies, and such a mechanism provides policy guarantee for the formation of good political-business relation.

\section{ANALYSIS ON STATUS OF CHINA'S UNITED FRONT'S AFFECTING POLITICAL-BUSINESS RELATIONS}

In recent years, China's united front has made great progress in building a good political-business relation in many aspects such as embedding condition, elite co-optation and absorption of public policy consultation. But there are still some problems in the current situation of the united front in China affecting political-business relation.

\section{A. The Actual Functional Effect of Organization Embedding Needs to Be Improved}

Under the conditions of our country, we have done a lot of work in organization embedding. However, the actual functional effect of organization embedding still needs to be further improved. Specifically, there are the following problems.

1) The willingness to work at the grassroots is not high: Though the actual functional effect is developed by strengthening non-public enterprises and social organizations in party building, the initiative of some enterprises and directors of social organizations for party building is not high. This phenomenon is very evident in private enterprises and foreign-invested enterprises. In these enterprises, the pursuit of production and operation and enterprise profit is the most important goal. While they think that party building work is not necessary, even they worry about party building may increase the possibility of enterprises being supervised and affect the profits of enterprises. Therefore, the difficulty of carrying out party building in these enterprises is significantly increased.

2) The effectiveness of grassroots party organizations is still relatively weak: Compared with state-owned enterprises, non-public enterprises and social organizations have different characteristics in terms of scale, structure and membership. These differences have increased the normalization of nonpublic enterprises and the party organizations of social organizations, and it needs to be improved no matter whether it is established or run. The specific performance is as follows: In terms of party members, the proportion of party members who are unemployed, moving and going out is relatively high. Some leaders of party organizations and some party branch secretaries do not have a strong sense of responsibility. In terms of working system, it is not uncommon of some party organization activities' poor development, not participating in organization activity for a long time and even not paying the fees of party membership. In terms of the guarantee mechanism, the data of some party organizations are not perfect, the party's construction funds are not included in the budget, and there are the problems of no site and no funds in the party activities. In terms of the performance and the masses' concerns, some party organizations lack of cohesion and combat effectiveness.

\section{B. The Operation Procedures and Procedural Arrangement of Elite Co-optation Need to Be Further Standardized}

In terms of elite co-optation, China has played a positive role. On the one hand, it increases the legitimacy of political system; on the other hand, it makes political participation further institutionalized. But at present, there are still the following problems.

1) There are potential risks in elite co-optation: The elite co-optation in essence is the combination of political elite and new economic elite, forming the "totality elites". This mode has expanded the channels and paths of new economic elite to obtain political information, increased its possibility and convenience to express its own interests, but also increased the possibility of rent-seeking behavior. In terms of some specific policies, some local governments and officials are biased towards economic elites. At the same time, it may increase the gap between elites and ordinary people and increase the social segregation to a certain extent, affecting the stability and harmony of the society.

2) In the form of elite co-optation, the administrative absorption and judicial absorption have institutional constraints: And in terms of personnel composition, the number of absorption of NPC and CPPCC members is still relatively low. The channels that new social class people are absorbed by political parties, NPC, CPPCC and other organizations are very smooth. But from the internal structure, the proportion of people in non-public-ownership economy and the proportion of people in other social strata absorbed by NPC and CPPCC are relatively low compared with the amount of absorption.

3) The operation lacks of the evaluation standard of scientific system and have the problems of formalization and vulgarization: There are some misunderstandings in the process of elite co-optation, such as that the main criterion is the economic strength of private entrepreneurs but lacks of evaluation of moral character and social responsibility. Even the evaluation criterion for consideration is the close and distant relationship with the main officials, which leads to rent-seeking behavior and the occurrence of cases. During the specific implementation, the problems of mechanism and working procedures have led to a series of problems such as large randomness, lack of overall planning and so on. 


\section{The Tendency of Decision-making on Public Policy Consultation and Further Improvement That the Innovation of Working Mechanism Needs}

China's united front has always been played a positive role in public policy consultation. Despite this, there are still the following problems.

1) The quality of suggestion and proposals should be further improved: The content of the topic is serious, which has poor pertinence and no adequate reflection of the general concerns of society. Some topics have become a tool for achieving departmental interests. For example, the topic which shall be applied for approval through the formal channel is changed to obtain the capital, which presents the characteristics of rent-seeking and utilitarianism. In addition to the democratic parties, almost no topic was raised by sectoral identities. And the topics raised by the parties show a high degree of convergence, which result in repeatability, similar proposals and repeated proposal contents.

2) In the public policy consultation, there is a situation of strong ability of individual participation in politics and a weak ability of collective participation in politics: Regardless of the number of people who put forward the proposals, these proposals have the same legal effect. But in theory, the increase in the number of people participating in political affairs in collective participation will accelerate the process of problem solution. And under the situation of strong ability of individual participation in politics and a weak ability of collective participation in politics, the mechanism of collective participation in political affairs shows a state of weakness. Therefore, this situation directly leads to that the adequacy of the role of political participation needs to be strengthened, and it also affects the basic functions of the NPC and CPPCC's playing the role of interest spokesmen. Due to this, the effectiveness of public policy consultation has been reduced, and its authority has been damaged.

3) The validity of handling still needs to be improved: According to the usual procedures, the handling of the proposal is to transfer it to various government departments separately for handing. But from the perspective of practical validity, this way of handling tends to have more stylization and more payable. In the content of proposal or reply, the declarative content is much more but the essential content is less. In terms of the transparency of the results, The actual settlement of proposals are just required to be replied to the representatives, members and relevant government departments who put forward the proposals, which lacks of rules and possibilities open to the public. In terms of the evaluation of results, because of the lack of the third party's evaluation mechanism, the evaluation is often made by representatives and members. With various social considerations, the representatives and members' evaluating the proposed proposals often lacks of truthfulness. Thus it affects the authentic assessment of the handling validity.

\section{RESEARCH ON INNOVATIVE COUNTERMEASURES OF CHINA'S UNITED FRONT IN DEALING WITH POLITICAL- BUSINESS RELATION}

A. To Further Expand the Coverage of Party Organizations in Economic and Social Fields in Terms of Organizational Embeddedness

1) The base number of emerging organizations should be accurately searched to obtain the basic data accurately: By comprehensively investigating the basic situation of nonpublic enterprises and social organizations, the foundation of non-public enterprises and social organizations shall be established from some aspects including business operation condition, organization setting, staff condition and party member base number. The verification of specific data of non-public enterprises and social organizations' registration, annual inspection and payment of profits and taxes shall be carried out by method of combining checking the documents and site confirmation. It can be also understood through reading the archives in some units such as the supervision bureau, civil affairs bureau and state tax and land tax. For grasping the actual scope of non-public enterprises and social organizations, we can conduct field verification and the frame comparison between the non-public enterprises and social organizations. It will exclude the original enterprises that exist in the archives and cover all the enterprises that should be unified. During the process of checking the party members, it is necessary to speed up the transfer of organizational relations of separating employee and get the organizational relations of new employee as soon as possible, so that the number of people will be found out.

2) We shall strengthen the team construction of nonpublic enterprises and social organizations: Party building instructors shall be assigned to non-public enterprises and social organizations, whose main role is to help the system construction for non public enterprises and social organizations. The instructors will also make these organizations continuously perfect in the aspects of "Three meeting and One - class", meeting of democratic life, democratic appraisement of party members and opening of the party affair, and give guidance in the work of original data collection, classifying, tidying and filing, and party member management. And it can further standardize the work of party organization and improve the validity of party organizational embeddedness.

3) We shall strengthen organization establishment and eliminate blank spots, so that the organization coverage is all in place: And we can adopt specific ways such as such as separate establishment, regional building associations, personnel establishment, affiliated establishment and industry unified construction. According to the situation of non-public enterprises and social organizations, the mode selection can be customized so as to improve the pertinence and effectiveness. It shall be ensured that the new party organization has funds for work and fields for activities 
through increasing investment, strengthening the guarantee of funds and field construction. Specific measures include that the party membership dues of party members of the new party organization can be paid back in full, and the funds for party building are included in the management expense and tax deduction.

\section{B. In the Elite Co-optation, the Target of United Front Work Should Be Mainly Oriented to the New Class, and the Key Is the Improvement of Absorption Mechanism and System Integration of Absorption Results}

1) To strengthen the elite co-optation in the new class: The new class mainly refers to the "four kinds of people", which are managerial and technical staff of private enterprises and foreign-funded enterprises, intermediary organizations and social organizations employees, internet professionals and freelancers. The stratified management shall be implemented for specific management. According to the specific conditions of different types of people, different classification methods and patterns are adopted to carry out the work. Concentrating on crucial points, we should strengthen the management of leading figures and core figures particularly. At the provincial level, at least 10 to 20 key people should be mastered in every field. The work should be carried out focusing on internal management in all fields. The management can not be carried out according to the conditions of administrative cadres. The management shall be flexible and effective. And it is necessary to prevent procedures and dogmatism. With the continuous development of economy, the database of new social class is constantly changing. Therefore, through the establishment of dynamic management mechanism, we should achieve the goal of absorbing qualified talents and eliminating backward personnel.

2) In the process of elite co-optation, we must establish a comprehensive and scientific evaluation standard: When selecting the evaluation standard, we should integrate the elements of ideological and political quality, status of fulfilling social responsibility, integrity and trustworthiness into the index system. And the evaluation results will be the main reference for non-public economic people's political arrangement and enterprise support. In terms of political arrangements, we should consider the two aspects of "politics" and "representativeness" so as to comprehensively consider the economic strength, social prestige, business behavior and the ability of discussing politics and achieve a political and representative unification. The mode of elite cooptation should be formed to a cultivated and guided mode. This mode before the political arrangements can play a more positive role in political absorption to a greater degree.

3) We must systematically integrate the consequences of elite co-optation and prevent the social risks caused by elite alliances: The direct result of elite co-optation must be an increasing scale of the new social stratum. Therefore, we need to deal with the relationships between the new factors and the original worker-peasant alliance and between the new elite and the public. In the current the political-business relation, the tendency of partial policies and behaviors towards economic elites is more and more obvious for a variety of reasons. This situation may aggravate social opposition, and such risk must be taken seriously and resolved.

\section{Promoting the Process of Legalization and Institutionalization of Consultation Absorption Mechanism on the Advisory Absorption}

1) We shall use the legislation to strengthen the degree of legalization of CPPCC political consultation, democratic supervision and political participation: In the construction of the relationship between government and business, the consultation absorption and game interaction between government and business are carried out mainly through the political consultation system. The institutionalization and legalization of the political consultation system can improve the situation that "politics" is in the dominant position and "commerce" is in the attached position in the current politicalbusiness relation, and it will make it develop towards an equal interaction. Meanwhile it is necessary to institutionalize the interactive relation between the NPC, CPPCC and the government. The transparency of three parties' information can form and establish a good mechanism with the three parties' recognition, cooperation and implementation. Thus, the formulation of public policy can make the three parties opinions consistent and achieve the absorption of consultation.

2) It is necessary to enhance the distinction and independence of the proposal: Distinction is the most effective carrier for the CPPCC to play its role. Therefore, it is necessary to strengthen the construction of the distinction. From the classification of distinctions, we should take full account of the following factors: occupation classification, organization resources. economic resources, possession condition of cultural resources, population structure, and characteristics of economic and social development, supplemental the new social stratum, etc. The boundaries of distinctions shall be determined by taking full account of these factors. The ways and means of distinction activities should be broadened and perfected through institutionalized approaches. The ability to express public opinion from different distinctions can be strengthened by improving the distinction activities' position construction, contact system, convener system and proposal collecting system.

3) To improve the handling mechanism of proposals: The whole processes of the NPC's suggestion and CPPCC's proposals shall be open and transparent. And a third-party evaluation mechanism shall be introduced to make an objective evaluation of the treatment effect, so as to supervise the government's main responsibilities to deal with suggestions and proposals. The third-party evaluation can be carried out by the method of "listening, watching, discussing and commenting". And it is necessary to conduct on-the-spot investigation and proposals and handling results through consulting relevant standing books concerning handling 
proposals. It can also be carried out through the methods of expert meeting discussions and organizers' reply. Democratic evaluation can be conducted through inspection research, discussions, convening of appraisal conferences and democratic evaluation. The organizers with poor evaluation results shall be notified and supervised to implement the "secondary handling".

\section{CONCLUSION}

China's united front has made great progress in building a good political-business relation and has achieved improvements in organizational embeddedness, elite cooptation and public policy consultation absorption. In the future, we should pay more attention to the path innovation in organizational embeddedness, elite co-optation and consultation absorption. In terms of organizational embeddedness, we should further expand the coverage of party organizations in the economic and social fields. In terms of elite co-optation, the object of united front work should be mainly oriented to the new class. In terms of consultation absorption, we should promote the constructing progress of legalization and institutionalization of consultation absorption mechanism and other innovations.

\section{REFERENCES}

[1] Zhang Yan'e: Action Mechanism of United Front in Dealing with Political-Business Relation and Its Transformation and Innovation[J]. Journal of Chongqing Institute of Socialism, 2016(1). 张艳娥: 统一战 线处理政商关系的作用机制及其转型创新 [J].重庆社会主义学院学 报,2016(1).

[2] Wei Wenxiang, Yang Tianshu: "Socialist Transformation" of National Elites and Chambers of Commerce: Taking the Wuhan Federation of Industry and Commerce as An Example(1949-1956)[J]. Journal of Huazhong Normal University (humanities and social sciences), 2005(5). 魏文享,杨天树：国家介人与商会的“社会主义改造”: 以武汉市工商 联为例(1949-1956)[J]. 华中师范大学学报(人文社会科学版),2005(5)

[3] The Subject of Shanghai Sociology Society: Research on the Action Mechanism that United Front Play in Social Negotiation[J]. Journal of Shanghai Socialist College, 2015(7). 上海市社会学学会课题: 统一战 线在社会协商中发挥作用机制研究 $[\mathrm{J}]$. 上海市社会主义学院学 报,2015 (7).

[4] Pan Xutao, Wang Fei: Half of Non-Public Enterprises Have Party Organizations[N]. People's Daily (overseas edition), 2015-06-30(4). 潘 旭涛, 王斐: 半数非公企业有了党组织 $[\mathrm{N}]$. 人民日报(海外版), 201506-30(4).

[5] Jin Yaoji: Administrative Absorption of Politics-Hong Kong's Political Models [M]. Our Country's Politics and Culture[M], Hongkong: Oxford University Press, 1997. 金耀基: 行政吸纳政治——香港的政 治模式[M].我国政治与文化[M],香港:牛津大学出版社,1997. 